\title{
A QUESTÃO DEMOCRÁTICA NA INGLATERRA DO SÉCULO XVII: SOBERANIA POPULAR, DIREITOS E SUFRÁGIO NO PENSAMENTO LEVELLER*
}

\author{
Javier Amadeo \\ Pós-doutorado pelo Departamento de História da Faculdade de Filosofia, Letras e \\ Ciências Humanas e professor de Teoria Política da Universidade Federal de São Paulo
}

\section{Resumo}

O objetivo do presente texto é sustentar a ideia que os levellers formaram um dos movimentos democrático-radicais mais importantes da história moderna, defendendo um programa político que articulava uma série de princípios que, no seu todo, configuravam uma proposta democrática. Estes princípios incluíam: a noção de soberania popular, de direitos humanos inalienáveis, o princípio de governo por consenso, a proposta de direitos políticos universais e a defesa da tolerância religiosa.

\section{Palavras-chave}

Levellers $\bullet$ história das ideias • teoria democrática.

\section{Correspondência}

Universidade Federal de São Paulo - Unifesp - Campus Guarulhos

Estrada do Caminho Velho, 333

Bairro dos Pimentas - Guarulhos - São Paulo - Brasil

CEP 07252-312

E-mail: javier.amadeo@unifesp.br

* O presente artigo é resultado de um projeto de pós-doutorado, em desenvolvimento no Departamento de História da Universidade de São Paulo, sob supervisão do professor Modesto Florenzano; o mesmo conta como o apoio financeiro da Fapesp. Gostaria de agradecer ao professor Florenzano pela revisão paciente e pelos valiosos comentários, no entanto assumindo que qualquer erro ou omissão é de minha exclusiva responsabilidade. 


\title{
THE DEMOCRATIC QUESTION IN THE SEVENTEENTH CENTURY: POPULAR SOVEREIGNTY, RIGHTS AND SUFFRAGE IN LEVELLER THOUGHT*
}

\author{
Javier Amadeo \\ Post-doctorate at the Departamento de História of Faculdade de Filosofia, Letras e \\ Ciências Humanas and professor of Political Theory at Universidade Federal de São Paulo
}

\begin{abstract}
The objective of the present text is to support the idea that the levellers had formed one of the more important radical democratic movements of modern history, defending a political program which articulated a series of principles that, in its all, configured a democratic proposal. These principles included: the notion of popular sovereignty, inalienable human rights, consensual government, universal political rights and religious tolerance.
\end{abstract}

\section{Keywords}

Levellers $\bullet$ history of the ideas $\bullet$ democratic theory.

\author{
Contact \\ Universidade Federal de São Paulo - Unifesp - Campus Guarulhos \\ Estrada do Caminho Velho, 333 \\ Bairro dos Pimentas - Guarulhos - São Paulo - Brazil \\ CEP 07252-312 \\ E-mail: javier.amadeo@unifesp.br
}

* The present article is resulted of a post-doctorate project develop in the History Department of the São Paulo University, under supervision of professor Modesto Florenzano; and the same counts with the financial support of Fapesp. I would like to be grateful to professor Florenzano for the patient revision and for the valuable commentaries, however assuming that any error or emission is of my exclusive responsibility. 
For really I think that the poorest he that is in England has a life to live as the greatest he; and therefore truly, sir, I think it's clear that every man that is to live under a government ought first by his own consent to put himself under that government; and I do think that the poorest man in England is not at all bound in a strict sense to that government that he has not had a voice to put himself under.

Colonel Thomas Rainborough At the General Councel of Army, Putney, 29 Octuber 1647

\section{Introdução}

O período da guerra civil inglesa (1642-1649) é de fundamental importância tanto para a história das ideias como para a teoria política moderna. Em um arco de tempo de não mais de meio século, observamos o surgimento de algumas das reflexões teóricas mais significativas do início da modernidade, dos escritos de Hobbes e Harrington, passando pelos levellers e por Winstanley, até Locke.

Neste período político sem precedentes, quando a velha ordem estava sendo abalada em seus alicerces, a reflexão dos grandes pensadores da época se orientou ao questionamento dos próprios fundamentos do poder político; e, ao mesmo tempo, homens comuns, que em tempos menos agitados permaneceriam em silêncio, tomaram a palavra. Como afirma Zagorin, só em tempos revolucionários os homens que normalmente permaneceriam silenciosos sobre suas Bíblias e queixas se movem para colocar suas exigências por escrito; no período analisado surgiram centenas de panfletos de protesto social e propostas de reforma que expressavam a voz de pequenos comerciantes, de artesãos e de camponeses de meados do século XVII. Desta forma, o pensamento político do período envolve uma riqueza dupla: por um lado, temos a racionalização sistemática dos teóricos políticos mais formidáveis e, por outro, a existência da agitação apaixonada e variada dos autores menos conhecidos dos panfletos (Zagorin, 1997, p. 1).

A questão democrática na Inglaterra do século XVII está intimamente relacionada com um desses grupos de indivíduos e ativistas políticos que surgiram no fulgor do conflito, os levellers. ${ }^{1} \mathrm{Na}$ história da teoria política, as ideias deste

Uma análise mais ampla das ideias e conceitos desenvolvidos nos séculos anteriores e que serviram de fundamento a uma concepção moderna de democracia fica fora das possibilidades do presente texto. No entanto, é necessário destacar que noções como soberania popular, direito de resistência, tolerância religiosa e o princípio consensual do poder político formavam parte das 
grupo são importantes por diversas razões. Os levellers, a partir de sua interpretação da lei da natureza, proclamavam que os indivíduos eram livres e iguais por nascimento e que o governo somente podia ser constituído a partir do consenso dos indivíduos. A tolerância religiosa e a igualdade dos indivíduos frente à lei eram outros dos pontos essenciais de sua concepção política. Sua preocupação com os direitos naturais os levou a tentar uma primeira proposta escrita de lei fundamental que não poderia ser alterada por nenhuma legislatura; e sua exigência de extensão do sufrágio foi a reivindicação mais radical que existiu até praticamente o século XIX na Inglaterra.

Em apoio de suas concepções, os levellers utilizaram elementos de diversas fontes teóricas, muitas vezes estenderam argumentos usados pelos parlamentares na sua luta contra o rei. Como afirma Rachael Foxley (2007), é possível assumir que a teoria dos levellers da soberania e dos direitos é um passo adiante no caminho argumentativo formulado pelos propagandistas parlamentares a partir de 1642. No momento em que líderes parlamentares, como William Prynne, podiam usar noções de consenso para proclamar "o poder soberano do Parlamento", os levellers, cada vez mais desconfiados com a atuação do Parlamento, podiam usar essas mesmas noções para proclamar a soberania popular. Os pensadores monárquicos, por sua vez, sugeriam que essa conclusão era meramente o resultado lógico dos argumentos dos parlamentares em sua resistência ao rei. Defensores do Parlamento, como Henry Parker, recusaram que uma conclusão deste tipo pudesse ser extraída. No entanto, a posição defensiva do argumento só aumentava a dúvida (Foxley, 2007, p. 642-3).

discussões de diversos movimentos radicais dos séculos XVI e XVII. Dentre estes movimentos podemos citar: o radicalismo calvinista desenvolvido por pensadores como John Knox, John Ponet e Christopher Goodman que chegou a conceber, por exemplo, a resistência à idolatria e tirania como um dever imposto por Deus a todo cidadão, e não só um dever dos magistrados, colocando argumentos em defesa da resistência popular. Filósofos da Contrarreforma da segunda metade do século XVI - entre eles autores como Bellermino e Francisco Suárez - têm sido apontados como os fundadores do pensamento constitucionalista moderno os quais chegaram a várias conclusões radicalmente populistas; uma inovação notável foi terem adotado uma concepção "subjetiva" de direitos, conceito que pode ser empregado para indicar uma capacidade que permite justificar certos tipos de ação normativa, como, por exemplo, o direito de resistência. Por sua vez, os pensadores da revolução huguenote desenvolveram e consolidaram posturas de juristas, como Bartolo ou Salamonio, e de teólogos, como Guilherme de Occam, Jacques Almain e John Mair já haviam assumido, porém chegando a conclusões mais radicais; estes pensadores - Teodoro Beza e Philippe du Plessis Mornay, entre outros - chegaram a afirmar que se a causa final para instituir uma república é o bem do povo, e a preservação de seus direitos, a única causa eficiente seria o consentimento geral, livremente expresso, de todos os cidadão envolvidos (Skinner, 2009). Para uma análise desses movimentos radicais ver: GOOCH, 1959; SKINNER, 2009 e BURNS, 2004. 
Se for verdade que vários dos argumentos utilizados pelos levellers têm como ponto de partida posições utilizadas pelos pensadores parlamentares, ao mesmo tempo é possível sustentar que os princípios políticos sustentados pelos levellers vão muito além das propostas parlamentares, constituindo um ponto de vista muito radical e irreconciliável em muitos aspectos com estas últimas.

O objetivo do presente texto é enfatizar a ideia que os levellers formaram um dos mais importantes movimentos democrático-radicais da história, defendendo um programa político que articulava uma série de princípios que, no seu todo, configuravam uma proposta democrática. Estes princípios incluíam: a noção de soberania popular, de direitos humanos inalienáveis, o princípio de governo por consenso, a proposta de direitos políticos universais e a defesa da tolerância religiosa. A articulação destes princípios deu lugar à construção de uma teoria radical da soberania popular ou de uma teoria democrática radical.

\section{0 princípio de soberania popular (contrato, consenso e dissolução do governo) ${ }^{2}$}

As características exatas do conceito de soberania defendido pelos levellers têm sido objeto de controvérsias. A visão padronizada da natureza da sociedade política que os levellers defendiam é que era uma forma de soberania popular diferente da parlamentar defendida por vários membros do Parlamento. ${ }^{3}$

Scott (2004), por exemplo, sustenta que a demanda fundamental dos pensadores levellers era um "autogoverno popular através dos representantes”. Wootton, por sua vez, também sustenta a ideia de uma noção de soberania popular, afirmando, no entanto, que esta posição a favor da soberania popular não estava livre de tensões e de ambiguidades, já que os levellers defenderiam a noção de "uma supremacia última do povo e de uma supremacia legal dos Comuns" (Wootton, 2004). A noção de soberania popular através dos representantes, ou do povo e dos representantes, cada um deles tendo algum tipo de soberania ou supremacia, provoca controvérsias sobre a real posição dos levellers em relação a esta questão. Rachel Foxley (2007) tenta mostrar as tensões irresolúveis entre a noção de soberania popular e de soberania parlamentar; para a autora a justifi-

\footnotetext{
2 A reivindicação de uma soberania de caráter popular tem vários precedentes no pensamento político moderno que vão além da disputa política inglesa; concepções sobre a soberania popular - como afirma Skinner $(2009$, p. 616) - já haviam sido articuladas nas obras de juristas radicais como Salamonio, nos tratados de occamistas como Almain e Mair, de calvinistas radicais importantes e também de pensadores do constitucionalismo como Suárez. Porém, as referências teóricas dos levellers estão centradas fundamentalmente no debate político inglês e na disputa entre o rei e o Parlamento e, portanto, serão nossa referência fundamental.

3 Sobre as controvérsias em relação a este ponto ver FOXLEY, 2007.
} 
cativa dos levellers para a soberania parlamentar faz com que a possibilidade de trair a confiança [trust $]$ seja de difícil explicação, e qualquer alternativa efetiva à soberania parlamentar impossível de imaginar.

Existem, sem dúvida, importantes ambiguidades e tensões no pensamento leveller em relação ao princípio de soberania popular; em parte, elas podem ser explicadas pela ausência de uma teoria política sistemática e por argumentos que muitas vezes foram modificados de acordo com a evolução do próprio conflito político. No entanto, acreditamos que há, no pensamento político leveller, uma série de princípios políticos democráticos - para diferenciá-los de uma teoria política sistemática - articulados entre si; e o princípio de soberania popular ocupa um lugar essencial nesta articulação. O princípio de soberania popular é resultado de uma série de noções que surgem nos panfletos políticos do período, como a ideia de lei natural, contrato, governo por consenso e dissolução do governo. Analisemos, portanto, como os próprios protagonistas abordavam este problema controverso.

Em The freeman's freedom vindication - A postscript (junho de 1646), John Lilburne, o principal líder dos levellers, declara que Deus enquanto soberano absoluto e Rei de todas as coisas no Céu e na Terra tem dado à humanidade:

[...] the sovereignty (under Himself) over all the rest of His creatures (Genesis I: 26,-7, 28-9) and endued him with a rational soul, or understanding, and thereby create him after His own image (Genesis I: 26,-7, 28-9). [all human beings since Adam and Eve] are and were by nature all equal and alike in power, dignity, authority and majesty, none of them having (by nature) any authority, domination or magisterial power, one over or above another (Sharp, 2004, p. 31).

O elemento central deste estado original é a igualdade dos indivíduos e a ausência de qualquer tipo de dominação entre eles. Ao mesmo tempo, Lilburne enfatiza características positivas e certos atributos da vida neste estado, que estão igualmente distribuídas, como poder, dignidade e autoridade. Os homens não devem exercer seu poder e autoridade natural sobre os outros, porém eles possuem estas qualidades neles mesmos e em relação ao resto da criação.

Em An arrow against all tyrants, Ricard Overton oferece, em uma linguagem mais técnica de autopropriedade, uma visão dos atributos do homem natural similar à visão de Lilburne sobre a dignidade e igualdade do homem no estado natural. Afirma Overton: "a cada individuo na natureza é dada propriedade individual por natureza para não invadir e usurpar a de ninguém [...] Por nascimento natural todos os homens são iguais e semelhantes para desfrutar de propriedade, liberdade e autonomia; e assim como somos colocados por Deus pela mão da 
natureza neste mundo, cada um com propriedade e liberdade naturais e inatas" (Sharp, 2004, p. 55).

Da mesma forma que na visão de Lilburne, para Overton o homem neste estado natural parece ter dignidade e autoridade. A sugestão no sentido de que algum tipo de poder é um atributo natural a todas as pessoas está reforçada pelo comentário de Overton sobre a fonte do poder político exercido pela Câmara dos Comuns: é a "soberania natural" do povo, seus "poderes e direitos naturais". A partir das premissas colocadas pelos pensadores levellers, fica ainda por resolver o problema dos mecanismos e acordos que produziram a sociedade política. Um estado de natureza tão pouco conflituoso não justifica necessariamente a decisão de entrar em uma forma radicalmente diferente de organização política, via contrato social. Um dos possíveis argumentos para fundamentar a necessidade da sociedade civil é afirmar que estas mudanças podem ter se precipitado por fatores pouco dramáticos como a sociabilidade e a necessidade de regulação social derivada do crescimento da complexidade social. Os levellers utilizam estes argumentos concedendo que os homens não nasceram para viver isolados, porém a noção de sociabilidade é fraca. Outra motivação para o surgimento do governo, em autores que têm uma concepção otimista da natureza humana, é a corrupção da natureza humana. Walwyn, por exemplo, segue o pensamento agostiniano quando afirma a necessidade humana de governo como resultado da queda do homem. ${ }^{4}$ Lilburne e Overton, por sua vez, utilizam como argumento o declínio moral e a queda, mas eles não estabelecem uma relação direta com a necessidade de um governo per se e sim com o surgimento de um governo tirânico e ilegítimo (Foxley, 2007, p. 646-7).

Os levellers não falam de "estado de natureza", mas sobre a lei da natureza. Ainda quando especificam que estão se referindo à lei natural "original", o funcionamento desta lei não precisa ser limitado ao passado pré-político. Para Overton, "a cada indivíduo na natureza, é dada uma propriedade individual", e assim "como nós somos colocados no mundo de Deus pela mão da natureza, cada um com liberdade inata e natural e propriedade", "desta forma devemos viver" (ênfase nosso). ${ }^{5}$ Overton não está descrevendo aqui o processo histórico que vai da liberdade natural até o governo, mas um conjunto de proposições sobre os direitos naturais que nós temos, e as circunstâncias nas quais podemos delegá-los. Os levellers não invocam um "estado de natureza" hipotético ou confinado ao passado, eles invocam os atributos naturais dos seres humanos e as provisões da lei natural,

${ }^{4}$ Cf. WALWYN. A manifestation; WOLFE, 1944, p. 388.

5 Cf. OVERTON. An arrow. SHARP, 2004, p. 55. 
ambos estendidos até o presente. Para Foxley a ideia de um "retorno" ao estado de natureza via dissolução do governo coloca um problema analítico importante, já que a divisão entre natureza e governo é problemática (Foxley, 2007, p. 650-1).

Embora os levellers tenham justificado suas demandas por referência a argumentos legais e históricos, eles utilizavam também argumentos baseados no direito natural que tinham um apelo claro, sem necessidade de recorrer a evidências e precedentes.

Lei da razão, Lei natural e Lei de Deus eram, na visão dos levellers, a mesma coisa. A Lei da natureza é a lei da autopreservação. O direito de autopreservação não só implica respeito em relação a direitos similares dos outros indivíduos, é também uma obrigação. Dada a Lei natural, que ensina através da razão a buscar segurança e bem-estar, ao mesmo tempo respeitando a busca similar dos outros, se segue que é injusto tanto oferecer como aceitar contratos que impliquem prejuízo para uma das partes. ${ }^{6} \mathrm{O}$ direito e a obrigação de autopreservação continuam dentro da sociedade, a que é, de fato, resultado do contrato. O estabelecimento do contrato não anulava os direitos dos membros para se retirar daquele acordo que é considerado injusto, ou desigual. A sociedade política existe como resultado de um contrato, isto é, por mútuo consentimento e acordo, ${ }^{7}$ sujeito às leis naturais ou leis da razão, tanto em geral, como no caso particular da república de Inglaterra. A sociedade política, sendo resultado de um contrato, estava sujeita aos mesmos critérios que outros contratos, isto é, não poderia haver desvantagens de uma parte em relação à outra, devia existir uma relação recíproca, caso contrário o contrato seria nulo. Ainda mais, qualquer poder adquirido por um corpo soberano permanecia "originalmente inerente ao povo". O poder outorgado em confiança [trust] estava também sujeito aos mesmos critérios que os contratos; e uma das formas em que os contratos e o poder em confiança podiam prejudicar uma das partes era através da aplicação parcial da lei. Um magistrado ou um governo que não respeitasse a justiça das leis destruía o governo da lei e dissolvia, ipso facto, o governo. O governo, negando a lei natural, provia um exemplo dos que destruíam os próprios princípios naturais e degeneravam em hábitos piores que

Cf. Legall fundamentall liberties. HALLER e DAVIS, 1964, p. 399.

7 "all particular or individual knit and joyned together by mutual consent and agreement, becomes a Soveraign Lord and King, and may creates or set apart, for the execution of their Lawes [...] Officers, which we call Magistrates [...] always provided, they be consonant to the Law of God, Nature and Reason by the force of which, it is not lawfull for any man to subject himself to be slave" (apud HAMPSHER-MONK, 1976, p. 415). 
os das bestas. O governo através de ações arbitrárias dissolvia a constituição civil de reino e colocava os indivíduos na condição natural original. ${ }^{8}$

Por volta de 1647, os levellers acreditavam que o governo havia sido dissolvido e o povo tinha retornado ao estado da natureza do qual só poderia emergir por meio de um contrato social; a tática dos levellers de apelar ao povo estava legitimada pela crença de que o governo estava dissolvido. O primeiro Agreement of the people foi publicado no outono de 1647, como plataforma para um acordo que instituísse os direitos e a leis fundamentais e, ao mesmo tempo, estabelecesse um pacto mútuo entre os indivíduos para colocar os princípios que serviram de base para o funcionamento do futuro governo. Um dos elementos fundamentais do Agreement era a necessidade de um consenso explícito por parte do povo para torná-lo legítimo: era necessária a adesão dos ingleses individualmente e não um simples ato do Parlamento. ${ }^{9}$

Para Zagorin, a concepção de um tipo de acordo como o proposto em Agreement era, sem dúvida, produto do pensamento coletivo dos levellers. No entanto, é possível ver uma influência decisiva de Lilburne e, em particular, de suas ideias. Para o autor o Agreement nunca poderia haver sido concebido sem a experiência de Lilburne na prática política das seitas e na crença no contrato como origem do governo e do consenso como fundamento. Foram essas ideias e experiência, unidas como a avaliação da situação política em 1647, os principais responsáveis por produzir esta forma de acordo sem precedentes. O primeiro Agreement era uma proposta de constituição democrática, porém era, também, muito mais. Era, ao mesmo tempo, a re-elaboração do grande mito do contrato social, de fato, era o próprio pacto por meio do qual a sociedade política era criada novamente, e a Inglaterra retirada do estado de natureza no qual, acreditavam os levellers, tinha se dissolvido (Zagorin, 1997, p. 14-5).

Em The out-cryes of oppressed commons (1647), texto escrito por Lilburne e Overton, aparece um elemento importante para entender a gênese do Agreement; eles afirmavam que:

Neste ponto retomamos o argumento de HAMPSHER-MONK, 1976, p. 415-7.

9 "An Agreement of the people is not proper to come from Parliament, because it comes from thence [...] but An Agreement of the People can never come justly within the Parliaments cognizance to destroy [...]". The legal fundamental liberties of the people of England. (HALLER e DAVIS, 1964). 
[the Parliamentary tyrants] dissolve the legall frame and constitution civill policy and government of the Kingdome, by suffering will and lust, but not lawe to rule and governe $u s$, and so reduce us into the best he can $[\ldots]^{10}$

A Inglaterra, no argumento dos levellers, se encontrava em uma situação de total ausência de justiça, em um estado de opressão, no qual os cidadãos estavam submetidos, simbolizada pelo aprisionamento dos líderes do movimento, e a recusa do governo em resolver as injúrias tinha dissolvido o país no estado de natureza; não existiam mais magistraturas verdadeiras. A imposição da tirania tinha dissolvido o governo legítimo. Era, portanto, imprescindível invocar o direito natural contra o Parlamento e convocar o estabelecimento de um novo governo.

Outro argumento no mesmo sentido aparece em An appeale from the degenerate representeative body (1647). Neste texto, Overton enfatiza a responsabilidade do Parlamento frente aos cidadãos. Porém, aqui, o apelo é dirigido diretamente ao Exército já que o Parlamento teria degenerado. Overton desenvolve uma justificativa teórica para esse apelo, admitindo a não existência de precedentes além da própria razão, e insistindo na traição do Parlamento. Como consequência desta traição, a autoridade deve retornar às pessoas que outorgaram essa autoridade [betrusters]:

All authority is fundamentally seated in the office, but ministerial in the persons; therefore, the persons in their Ministrations degeneration from safety to tyranny, their Authority ceaseth and is only to be found in the fundamentall, rise and situation thereof, which is the people the body represent [...] [authority] alwayes is either in the hands of the Betrusted or of the Betrustees, while the Betrusted and discharges of their trust, it remaineth in their hands, but no sooner the Betrusted betray and forfeit their Trust, but (as all things else dissolution) it returneth from whence it came, even to the hands of the Trustees: For all iust humaine power are but betrustes, confer'd and conveyed by iont and common consent [...] (Wolfe, 1944b, p. 162).

Como afirma Foxley, os levellers, ao acusar o governo de haver degenerado e traído a confiança, apelam incontestavelmente ao povo. Overton justifica a perda do poder da Câmara dos Comuns, outorgado em confiança, como resultado das ações dos representantes, e coloca junto a esta sentença uma explicação da inerência natural do poder nos indivíduos e de sua escolha dos representantes com o objetivo de utilizar esse poder para seu bem-estar. Ocorre que quando o poder, ou a autoridade soberana,

${ }^{10}$ Esta ideia também aparece em The legal fundamental liberties. O Parlamento, pelas suas ações arbitrárias, havia "dissolved the whole frame and constitution of the Civil Policy and Government of this Kingdom into the originall Law of Nature" (HALLER e DAVIS, 1964). 
é confiscado, este reverte para o povo, de onde ele se origina (Foxley, 2007, p. 654); como consequência do argumento utilizado por Overton, fica claramente estabelecido que a soberania última do poder político reside no povo.

A partir da premissa de que a Inglaterra havia sido reduzida ao estado de natureza, e que o poder soberano outorgado ao Parlamento tinha sido confiscado, o problema era mais importante que simplesmente formular uma lei fundamental que o Parlamento devia proclamar. O Parlamento, enquanto corpo representativo legítimo, não existia mais. A tarefa consistia em reconstituir a sociedade política. Para os levellers não existia distinção clara entre o pacto que criava a sociedade e o que criava o governo, era necessário fazer um contrato político e social novamente.

O Agreement propunha quatro medidas centrais para superar a situação de crise na qual se encontrava a Inglaterra. Estas eram: 1) redistribuição do número de membros do Parlamento em relação com a quantidade de habitantes; 2) dissolução do Longo Parlamento em 30 de setembro de 1648; 3) eleições parlamentares a cada dois anos, com Parlamentos escolhidos por seis meses; 4) supremacia da Câmara dos Comuns, cujo poder seria "somente inferior ao daqueles que o escolheram". ${ }^{11}$

O último ponto mencionado no Agreement é fundamental; nele fica claramente afirmado o conceito de soberania popular; existia um poder superior ao da Câmara dos Comuns que era o poder dos representados. Este conceito de soberania popular se concretizava fazendo referência a um número de poderes reservados pelo povo a eles mesmos: os assuntos relativos à religião deviam ser deixados à consciência individual; ${ }^{12}$ não poderia haver nenhum constrangimento para servir nas guerras; ninguém poderia questionar nada do dito ou feito durante a guerra civil; todos deviam ser tratados como iguais ante a lei; e, por último, se afirmava que as leis deviam ser boas e não evidentemente destrutivas para a segurança e bem-estar do povo. ${ }^{13}$ Existia, na elaboração da proposta, uma série de elementos de caráter prático colocados pelos levellers com o objetivo de proteger os soldados de represálias futuras; no entanto, o fundamental é a ideia central de que determinados assuntos ficavam reservados, fora de qualquer ato do Parlamento. O fundamento último destes direitos era a soberania do povo, frente à qual os representantes nada podiam alegar.

A proposta de um acordo fundacional na forma do Agreement of the people é uma das evidências mais importantes da força inerente da ideia de contrato e

${ }^{11}$ Cf. Agreement of the people. WOLFE, 1944, p. 225-234.

${ }^{12}$ Retomaremos este ponto na discussão sobre a tolerância religiosa.

${ }^{13}$ Sobre este ponto ver GENTLES, 2001, p. 148-173. 
de soberania popular no pensamento político dos levellers. Para os membros do movimento, a ideia de contrato social e de governo por consenso não era meramente uma premissa hipotética de ordem política, ou, se tinha um caráter histórico, não era como um ato instituído uma vez e para sempre no passado distante. Ele era uma fonte literal e permanente da existência política comum. Se a existência fosse destruída pela tirania, somente o contrato social poderia restabelecê-la. A concepção básica do Agreement ia além da ideia de um princípio constitucional, apresentando-se nos próprios termos do contrato social nos quais devia entrar se a ordem política devia ser restabelecida. Para Zagorin (2007, p. 16-17), o Agreement marca o ponto mais radical da proposta democrática dos levellers: seu individualismo, expresso na reivindicação de que somente o consenso dos cidadãos individuais outorgaria legitimidade ao Agreement; sua crença no contrato social, que o Agreement literalmente tentava ser; sua fidelidade ao princípio de direito natural, cuja transferência o Agreement tentava efetivar; e, finalmente, seu apelo à soberania popular, fonte última da legitimidade política.

Wootton (2004, p. 433-4), por sua vez, afirma que o princípio de soberania popular é mais importante no pensamento leveller do que a questão constitucional ou a extensão dos direitos políticos; este princípio oferecia uma proteção segura para os direitos naturais por eles também reivindicados.

Como se vê, o pensamento político dos levellers, em relação à soberania popular, marca o ponto mais radical do pensamento democrático inglês do século XVII, e se tornará uma de suas expressões mais clássicas.

\section{Direitos naturais inalienáveis}

O conflito entre o Parlamento e a Coroa colocou novos elementos para a discussão política e o apelo ao precedente se tornou insuficiente. A visão política tradicional na sociedade inglesa enfatizava o costume e a lei como fundamento do poder político. Porém, com o processo de radicalização houve uma busca por fundamentar o poder com base em princípios diferentes, como vimos anteriormente, e houve também uma mudança de ênfase do precedente da lei para a lei natural, dos direitos históricos para os direitos naturais. Do ponto de vista da história das ideias, as teorias do direito natural colocavam uma série de elementos fundamentais para o debate inglês, transformando muitas das questões em disputa. $\mathrm{O}$ recurso à razão em contraste com o apelo à história tinha uma conveniência política fundamental, pois permitia não simplesmente a defesa dos direitos existentes, mas a luta pela extensão dos mesmos. 
Na primeira parte dos anos de 1640, foram publicados na Inglaterra alguns dos trabalhos mais importantes da tradição conservadora dos direitos naturais, assim como também obras que constituíam uma corrente radical de falar de direitos naturais. Como afirma Tuck, a elaboração teórica de Grotius permitia prover a linguagem básica para as duas tradições: os conservadores recuperavam a ideia central de que os homens livres eram capazes de renunciar às suas liberdades, ao mesmo tempo em que os radicais recuperavam o princípio da caridade interpretativa [interpretative charity] aplicado para acordos políticos fundamentais. Este princípio implicava direitos inalienáveis: logicamente, os homens livres eram capazes no estado de natureza de renunciar a todos os direitos para sobreviver ou para se liberar, porém a caridade [charity] requeria que assumíssemos que eles não tinham de fazer isso. Nossos ancestrais, sendo racionais, não deveriam querer que ficássemos completamente desprovidos de nossos direitos por terem eles perdido os seus. Grotius, sempre de acordo com Tuck, havia invocado o princípio da caridade interpretativa para defender a resistência política e reivindicações de posse comum de propriedade em casos extremos para preservar a vida humana, e este era o argumento que apareceria ano após ano nas posições políticas dos pensadores radicais ingleses. Não existia razão para supor que todos os que usassem esse argumento tinham lido Grotius: a caridade interpretativa era um princípio usado com o objetivo de modificar uma teoria forte dos direitos naturais e, no momento em que a linguagem dos direitos naturais se tornou suficientemente comum, podia ser desenvolvida independentemente do pensador holandês (Tuck, 1979, p. 142-3).

Um exemplo de argumentação baseada nas teorias do direito natural, em uma perspectiva não conservadora, é o texto de Henry Parker, Observation upon some of his majesties late answers and expresses (julho de 1642), um dos panfletos mais influentes do período. Parker, com o objetivo de refutar as reivindicações de poder absoluto feitas pelos partidários do rei, utilizou uma combinação do princípio de caridade interpretativa e da ideia tradicional de obrigação [duty] natural de autodefesa para argumentar que as pessoas sempre deviam reservar direitos para si em qualquer acordo com seu soberano. Para explicar a relação existente entre soberano e povo, Parker utiliza um conceito chave no pensamento político do período, e que será retomado pelos levellers, a noção de trust. ${ }^{14}$

\footnotetext{
${ }^{14}$ I conceive it is now sufficiently cleared, that all rule is but fiduciarie, and that this and that Prince is more and lesse absolute, an he is more or lesse trusted, and that all trusts differ not in nature or intent, but in degree only and extent: and therefore since it is unnuturall for any Nation to give away its owne propiertie in it selfe absolutely, and to the supreme of all Lawes, wee must not think that it can stand with the intention of any trust, that necessarie defence should be barred, and naturall preservation denied to any people. PARKER, Henry. Observation upon some of his majesties late answers and expresses. London, 1642.
} 
Para Parker o bem-estar das pessoas devia ser o fim último, o qual nunca podia ser confiado ao arbítrio do monarca, e este fim era mais importante que qualquer meio. Em Observations, Parker usa a noção de direito inalienável exclusivamente no contexto de defesa dos direitos da comunidade como um todo contra seu governante. Mas quando seus oponentes monarquistas o confrontam sobre este ponto argumentando que indivíduos pré-sociais devem renunciar a todos os seus direitos, Parker vê-se forçado a considerar a possibilidade de direitos individuais inalienáveis. Em um texto posterior, Jus populi (outubro de 1644), defendendo-se de seus críticos, Parker, como bem mostrou Tuck, repudia explicitamente a teoria de Grotius de autocracia voluntária e nega a possibilidade de indivíduos racionais se transformarem em escravos. O argumento de Parker vai em direção a aceitar uma teoria dos direitos individuais inalienáveis, inclusive no próprio Jus populi, mas ao mesmo tempo está determinado a explicar os males da escravidão como resultado, em parte, de uma violação dos direitos sociais (Tuck, 1979, p. 146-7).

Esta ambiguidade é interessante e mostra que existiam diversas possibilidades de articulação entre conceitos como direitos inalienáveis, obrigação política, resistência e liberdade, entre outros, a partir do uso da linguagem dos direitos naturais. E, ao mesmo tempo, expõe a desconfiança em relação às consequências políticas de uma linguagem política nova e com implicações não totalmente claras, como mostraram as discussões ao longo da guerra civil.

Parker estava, teórica e politicamente, comprometido com os líderes do Exército e com o Parlamento, e sua autoridade tinha de ser salvaguardada, ao mesmo tempo em que a autoridade do rei tinha que ser debilitada; e a maneira óbvia de fazê-lo era enfatizando os direitos da comunidade como um todo. Porém, a partir do processo de radicalização, resultado do processo de mobilização política, alguns pensadores começaram a usar a doutrina dos direitos inalienáveis contra o próprio Parlamento e contra os líderes do Exército. Os levellers retomaram a ideia de direitos individuais inalienáveis e insistiram que o Parlamento teria usurpado esses direitos; a resposta frente a este desafio era que os direitos individuais deviam estar subordinados aos direitos sociais coletivos.

Lilburne, em Englands birth-right justified (1645), sustentando a posição de que o Parlamento devia atuar de acordo com a lei, afirmava:

[...] take away the declared, unrepealed Law, and then where is Meum and Tuum, and Libertie, and Propertie? But you will say, the Law declared, binds the People, but is no rule for Parliament sitting, who are not to walke by a knowne Law. It is answered: It cannot be imagined that ever the People would be so sottish, as to give such a Power to those whom they choose for their Servant; for this were to give them a Power to provide 
for their woe, but not for their weal, which is contrary to their own foregoing Maxime (Aylmer, 1975, p. 57).

No entanto, um dos exemplos mais extraordinários de utilização da linguagem dos direitos pelos levellers são os panfletos políticos de Richard Overton, em particular An appeale from the degenerate representeative body (1647), no qual afirmava:

[...] for the every individual in nature, is given individuall propriety by nature, not be invaded or usurped by any [...] for every one as he is himself hath a self propriety, else could not be himselfe, and on this no second may presume without consent; and by natural birth, all men are equall and alike borne to like propriety and freedome, every man by naturall instinct aiming at his owne safety and weale [...] Now as no man by nature may abuse, beat, torment or afflict himself, so by nature no man may give that power to another seeing he may not doe it himselfe [...] (Wolfe, 1944, p. 162).

Neste texto, Overton coloca no centro de sua teoria um direito inalienável particular, o direito de autopreservação, derivando este direito de um conjunto mais amplo ao qual nenhum ser racional pode renunciar. Partindo deste princípio, Overton propõe uma luta pela recuperação dos direitos e liberdades humanas naturais; e afirma que todas as ordens, classes e sociedades dos nascidos no país podem desfrutar total e livremente uma coabitação mútua e uma subsistência humana (Wolfe, 1944, p. 156-188). O argumento de Overton afirma que qualquer coisa que seja razoável desejar pode se constituir em um direito inalienável, estando sua recuperação inteiramente justificada; e, ao mesmo tempo, sustenta a impossibilidade de que um homem racional renuncie a seus direitos. Neste ponto é possível ver que o princípio de caridade interpretativa foi ampliado de forma tal que chegou muito perto da noção do século XVIII de direitos inalienáveis da humanidade (Tuck, 1979, p. 149-50).

No entanto, se os levellers defendiam os direitos individuais, eles aceitavam que as sociedades podiam ser sujeitos de direito também, pois o objetivo fundamental dos pensadores do movimento era que os indivíduos tivessem o mesmo tipo de direitos. A linguagem empregada nesta esfera é similar àquela utilizada pelos independentes, que defendiam a captura do rei argumentando que cada membro da nação devia contribuir com sua preservação tanto quanto fosse possível. Por outro lado, era frequente descrever os direitos das sociedades em termos de direitos individuais, como faz, por exemplo, Overton também em Appeale:

[...] all degrees and titles Magisteriall, whether emperial, regall, Parliamentarie, or otherwise are all subservient to popular safety, all founded and grounded thereon, all 
instituted and ordained only for it, for without it can be no humane society, cohabitation or being, which above all earthly things must be maintained, as the earthly soveraigne good of mankind, let what or who will perish, or be confounded, for mankind must be preserves upon the earth, and to this preservation, all the Children of men have an equal title by Birth, none to be deprived thereof, but such as are enemies thereto [...] (Wolfe, 1944, p. 178).

Overton afirma que os homens também possuem - além do direito natural e inalienável de se proteger a si mesmos como indivíduos - o direito inalienável de exigir que a comunidade a qual pertencem seja protegida e preservada; ainda que expresse este ponto de forma incomum, ele representa um aspecto decisivo do pensamento leveller. Os críticos dos levellers, como o próprio Henry Parker, aproveitaram essas inconsistências para formular seus ataques. Em An answer to a paper, entituled, some considerations, Parker afirma que a liberdade é um direito de nascimento para todo inglês, porém esta liberdade tem seus limites e suas regras e a liberdade de cada membro devia estar subordinada à liberdade do corpo inteiro. Pelas leis da liberdade cada homem pode desfrutar daquilo que lhe é próprio; no entanto, por último, existe a liberdade da comunidade como um todo, assim como existe a liberdade de cada sujeito particular, e a liberdade da comunidade deve exceder a liberdade de cada indivíduo particular, e quando elas entrarem em conflito a menos importante deve dar lugar à mais importante (Tuck, 1979, p. 150-1).

Este tipo de argumento buscava limitar a possibilidade de pensar em termos de direitos individuais inalienáveis. Estes deviam estar subordinados aos direitos do corpo social. Este argumento formulado por Parker será retomado pelos líderes do Exército nos debates com os levellers, como veremos; Ireton atacará os argumentos a favor da liberdade negando que a caridade interpretativa possa ser aplicada aos indivíduos.

Os argumentos em relação aos direitos naturais e aos direitos sociais eram complexos e não são fáceis de seguir ao longo das diversas controvérsias do período revolucionário. Um dos momentos mais intensos e dramáticos dos debates políticos no período revolucionário foram os debates de Putney, entre os líderes do Exército e os agitadores, e em que os argumentos baseados em direitos históricos e direitos universais aparecem no centro da discussão. ${ }^{15}$

Durante os debates de Putney, os agitadores sustentavam o direito inalienável de todo inglês, independentemente de sua propriedade, de ter direitos políticos, questionando, a partir de princípios universais, os direitos políticos e

${ }^{15}$ Uma discussão mais detalhada sobre os debates de Putney será feita no item seguinte, aqui só analisaremos os argumentos relativos aos direitos naturais. 
sociais existentes, inclusive a propriedade da terra. Os levellers apelavam à lei natural e afirmavam que era esta lei que ensina ao indivíduo seus direitos e suas obrigações: o direito e a obrigação de autopreservação e os limites naturais da obediência - ou o direito e obrigação de resistência a um governo tirânico. A lei natural ensina qual era o fim do governo; e inculcava os princípios básicos da vida social, os princípios da justiça natural e da equidade que ditavam a igualdade política de todos os homens frente ao Estado. Por trás do apelo dos levellers à lei natural estavam os argumentos utilizados pelos parlamentares contra o rei, e pelo Exército contra ambos, Parlamento e rei. Em 1642, os apologistas do Parlamento declaravam que a lei natural era a lei suprema e que o poder era originalmente inerente ao povo, e a fonte da autoridade dos magistrados não podia ser outra que as ações e acordos das corporações políticas. Com uma enorme autoridade e com uma liberdade nova a partir de sua referência nela mesma, a lei da natureza era a fundação do credo político dos levellers e corte final de apelação (Woodhouse, 1974, p. 91).

Os líderes do Exército, Cromwell e Ireton, por sua vez, insistiam em que existiam compromissos que as convicções dos homens não podiam anular, e que havia estruturas da lei positiva contra as quais a "lei da natureza" não era argumento suficiente.

[Ireton]: Give me leave to tell you, that if you make this the rule I think you must fly for refuge to an absolute natural right, and you must deny all civil right: and I am sure it will come to that in the consequence (Woodhouse, 1974, p. 53).

O argumento dos líderes do Exército sustentava que a propriedade devia ser distribuída de acordo com arranjos sociais e não a partir de princípios universais. A propriedade era fundada pela constituição. Eram a lei e os costumes do reino que deviam dar ao indivíduo seus direitos, tanto políticos como sociais, estes não podiam ser deduzidos a partir de direitos naturais.

[Ireton]: The Law of God doth not give me property, nor the Law of Nature, but property is of human constitution. I have property and this I shall enjoy. Constitution founds property (Woodhouse, 1974, p. 69).

Para os líderes do Exército, comprometidos com a conservação da ordem social, as instituições sociais faziam do homem o que ele era; e como consequência, o indivíduo vivia e era obrigado pela estrutura da lei humana que não era resultado de sua criação. Este sistema social criado pela commom law era uma estrutura que definia os modos de possuir, herdar e transmitir a terra em termos de costume imemorial; e os únicos indivíduos que os líderes do Exército em geral, 
e Ireton em particular, estavam dispostos a admitir na participação cívica eram aqueles que "tivessem um interesse permanente no reino" (Woodhouse, 1974, p. 66), isto é, aqueles que tivessem um mínimo de terra como posseiros livres.

Como afirma Woodhouse (1974, p. 95), o apelo à razão tinha como contraparte um tipo de atitude com relação ao precedente histórico. Nas etapas iniciais da oposição ao absolutismo, superpunham-se dois apelos, um recurso para o precedente e outro para a lei suprema conhecida pela razão, que podia ser descrita como lei da natureza. As leis positivas exigiam obediência, enquanto expressão singular, e incorporavam a lei fundamental de forma aproximada. Apelar ao precedente não implicava negar a lei superior e sim presumi-la de forma silenciosa. Esta era a posição de Lilburne em London's liberty in chains (1646). Neste panfleto o pensador leveller recorria ao Livro dos Estatutos e à Carta Magna, e a outros direitos históricos da Inglaterra para justificar sua posição. Porém, a luta do Parlamento com a Coroa, e o conflito do Exército com o Parlamento, colocaram novos elementos para a discussão política e o apelo ao precedente se tornou insuficiente. A visão puritana predominante sobre o costume e a lei junto com as novas teorias sobre o fundamento do poder político, resultaram em uma mudança de ênfase do precedente da lei para a lei natural, dos direitos históricos para os direitos naturais. Este era o ponto de divisão entre Ireton e os levellers. O apelo à razão em oposição à história tinha uma vantagem política central, permitia a extensão dos direitos, e não simplesmente a defesa dos direitos já existentes.

Os debates no interior do Exército dão testemunho da versão mais radical do pensamento político do período, fundamentado no direito natural. Se, por um lado, existe um apelo às liberdades do reino fundadas no costume imemorial, por outro, os agitadores vão propor, com base na linguagem dos direitos, uma ação política radical fundada na crítica das leis e liberdades herdadas do passado.

\section{Sufrágio, propriedade e Debates de Putney}

Um dos pontos mais importantes do pensamento político leveller era a exigência de direitos políticos amplos, ou inclusive com a reivindicação do sufrágio universal (masculino).

A demanda dos levellers de uma ampla participação popular na eleição dos membros do Parlamento tem sido vista como resultado de duas influências, de caráter prático, fundamentais (Thomas, 1972). A primeira se relacionava com a doutrina espiritual protestante de igualdade dos crentes; esta doutrina tinha gerado o modelo de congregações religiosas, cujos membros participavam por igual na eleição dos ministros e na tomada coletiva de decisões. A segunda foi 
resultado do colapso da ordem política inglesa sob a pressão da guerra civil. Esta situação deu lugar à construção de uma nova ordem e deu uma justificativa aos membros do Novo Exército Modelo em sua reivindicação de uma maior participação no poder político. No entanto, as propostas dos levellers não resultavam unicamente da guerra civil e das práticas das seitas religiosas; suas raízes estavam arraigadas na própria estrutura política da sociedade inglesa. Uma das características distintivas da Inglaterra dos Tudor e dos Stuart era um maior grau de participação no governo local, comparado com outras sociedades europeias do mesmo período.

Existia, no âmbito político inglês, desde a Idade Média, uma quantidade importante de instituições de governo local, como comitês administrativos de paróquias, cortes de justiça e conselhos de administração local, que haviam habituado seus membros a participar na elaboração dos regulamentos, indicação de oficiais e recolhimento de tributos. Neste contexto, os membros das comunidades ficaram habituados ao uso de procedimentos "democráticos", como decisões por maioria - como em encontros comunais em Northampton-shire no século $\mathrm{XV}$ - ou votações por cédulas. As eleições parlamentares também ofereciam antecedentes importantes na luta pela ampliação do sufrágio. Existiam regulações que limitavam o eleitorado no nível distrital aos proprietários de terra com uma determinada renda anual, porém, ao mesmo tempo, existiam condados nos quais as qualificações mínimas não eram observadas de forma estrita. A situação nos distritos era muito dinâmica. O movimento a favor da ampliação do sufrágio nos distritos eleitorais entre o reinado de Jaime I até Guilherme III foi intenso. Em muitas cidades, havia uma incerteza genuína sobre quem exatamente possuía direito a votar, e cada eleição geral levantava numerosas disputas eleitorais (Thomas, 1972, p. 61-2).

As propostas dos levellers em relação ao sufrágio foram precedidas por décadas de agitação em favor da ampliação dos direitos políticos; este movimento tinha conseguido algumas vitórias importantes, ampliando o sufrágio em determinados distritos e chegando a colocar alguns milhares de indivíduos nas eleições. A existência desse eleitorado emergente contribuiu para colocar em pauta o problema da representação e os debates em torno dela. Quando os levellers exigiram direitos políticos para todos os habitantes, esta demanda era, em parte, resultado das experiências distritais, as quais eles tinham observado ou tomado conhecimento.

Do ponto de vista teórico, a experiência pré-revolucionária também oferecia importantes elementos para a exigência do sufrágio. Pensadores políticos do século XVII criticavam o estatuto de 1430 por haver tirado o direito de voto de pessoas 
que anteriormente tinham esse direito. William Noy, em 1621, declarava que "Antigamente toda a comunidade tinha voz, mas por causa dos feitos da multidão nas eleições tumultuosas foi depois reduzido aos proprietários". A mesma teoria da perda de direitos políticos foi reiterada por William Prynne "Antes da Petição e Ato todos os habitante e comuns em cada condado tinham voz na eleição, tanto se eram proprietários como se não o eram". Para os levellers, argumentos deste tipo tiveram uma importância decisiva. Em Londons liberty in chains discovered (1646), John Lilburne se lamentava da perda do direito de sufrágio de milhares de pessoas pelo "estatuto injusto e restritivo" e instava para que fossem tomadas medidas para "restaurar a cada homem livre da Inglaterra seus direitos e liberdades naturais e legais". Por sua vez, os autores levellers da Petition of January (1648) censuravam que o Ato os tinha privado de seus direitos, "Era uma antiga liberdade desta nação que todas as pessoas nascidas livres escolhiam livremente seus representantes no Parlamento" (Thomas, 1972, p. 64). ${ }^{16}$

Os levellers modificaram os argumentos da vindicação do sufrágio, eles passaram de fundamentá-lo no direito histórico para reivindicá-lo a partir do direito natural, porém o argumento histórico original foi legado dos defensores parlamentaristas de começo do século XVII. Para uma ideia mais precisa da posição dos levellers, e também de outros grupos puritanos, em relação aos direitos políticos devemos voltar nossa atenção para os debates, gerados pelo processo de mobilização política, no interior do novo Exército modelo.

Os famosos Debates de Putney, transcritos por William Clarke, ${ }^{17}$ entre $28 \mathrm{de}$ outubro e $1^{\circ}$ de novembro de 1647 , têm sido vistos comumente como centrais na história do movimento leveller. A razão disto é que as ideias mais importantes discutidas nesses dias eram ideias levellers, e os documentos que propiciaram os debates faziam parte da campanha leveller para buscar realizar suas ideias de governo a partir do apoio do Exército. Muitos dos líderes do movimento acreditavam que a melhor forma, ou talvez a única, de re-fundar a sociedade política inglesa com base no Agreement of the people, que analisamos anteriormente, era obter a adesão do Exército e empregar sua força para coagir ou dissolver o Parlamento. ${ }^{18}$

O Conselho Geral do Exército, presidido pelo próprio Oliver Cromwell, reuniu-se em Putney, em outubro de 1647, para discutir as demandas apresenta-

${ }^{16}$ Cf. WOLFE, 1944b, p. 269.

${ }^{17}$ Sobre o manuscrito de Clarke, ver LE CLAIRE, 2001.

${ }^{18}$ Para a transcrição dos Debates de Putney ver WOODHOUSE, 1974, p. 1-124, realizada a partir dos Clarke papers. Para uma análise dos debates do ponto de vista filológico e do contexto histórico ver, MENDLE, 2001. Para uma análise do papel do exército e de sua posição nos debates ver KISHANSKY, 2003 e WOOLRYCH, 2002. 
das pelos agitadores. Os objetivos dos líderes do Exército - Fairfax, Cromwell e Ireton - eram em aspectos vitais incompatíveis com aqueles dos porta-vozes levellers em Putney. Desta forma, os debates representaram uma disputa crucial de poder assim como um embate em torno de princípios políticos. Um dos pontos centrais era a questão dos direitos políticos e, em decorrência, a relação entre estes e o direito de propriedade. Um breve olhar sobre parte dos debates pode nos dar uma ideia de quais eram os argumentos centrais em conflito colocados tanto pelos levellers como pelos líderes do Exército.

A proposta original de discussão nos debates de Putney, em 28 de outubro, era The case of the armie truly stated (15 de outubro de 1647) (Wolfe, 1944b, p. 196-222), na qual a cláusula sobre o sufrágio era mais explícita, porém na discussão que recomeçou no dia 29, esta tinha sido substituída pelo Agreement, e a discussão centrou-se particularmente no primeiro ponto que definia o problema da eleição dos representantes. ${ }^{19}$

Ireton iniciou as discussões sobre este ponto afirmando que, apesar da redação ambígua do primeiro ponto do Agreement, este podia sem dúvida ser considerado como uma afirmação do direito universal ao sufrágio:

[Ireton]: The exception that lies in it is this. It is said, they are to be distributed according to the number of inhabitants: "The people of England". And this doth make me think that the meaning is, that every man that is an inhabitant is to be equally considered, and to have equal voice in the election of those representers (Woodhouse, 1974, p. 52).

A afirmação de Ireton parece indicar que ele conhecia ou pressupunha qual era a posição dos levellers sobre o assunto dos direitos políticos; assim podemos supor que isto evidencia que esta era a proposta sobre o sufrágio, que comumente os contemporâneos dos levellers atribuíam a eles, anteriormente aos debates de Putney (Hampsher-Monk, 1976, p. 398).

Frente a este desafio, os porta-vozes dos levellers - Nicholas Cowling, Maximiliam Petty e Thomas Rainborough - deram respostas similares; Cowling se refere ao suposto sufrágio universal existente antes da Conquista Normanda. Petty exclui do sufrágio somente aqueles que perderam seus direitos de nascimento, como os delinquentes. Finalmente, Rainborough baseia a demanda de direitos

${ }^{19}$ Agreement of the people: "I. That the people of England, being at this day very unequally distributed by counties, cities, boroughs, for the election of their deputies in Parliament, ought to be more indifferently proportioned according to the number of the inhabitants; the circumstances whereof, for number, place, manner, are to be set down before the end of this present Parliament" (WOODHOUSE, 1974, p. 443-4). 
políticos no direito de nascimento dos ingleses e, fundamentalmente com base no direito natural, chega a sustentar de forma inequívoca a posição favorável a direitos políticos universais:

[Rainborough]: For really I think that the poorest he that is in England has a life to live as the greatest he; and therefore truly, sir, I think it's clear that every man that is to live under a government ought first by his own consent to put himself under that government; and I do think that the poorest man in England in not at all bound in a strict sense to that government that he has not had a voice to put himself under (Woodhouse, 1974, p. 53).

Para Hampsher-Monk, e concordamos com sua leitura, para entender a real significação de Putney, os argumentos têm que ser lidos "como um debate", no qual os levellers argumentaram a favor do sufrágio universal, porém sem obter sucesso no término da discussão. Para o autor, os argumentos de princípio colocados pelos participantes do debate só podem ser entendidos como argumentos a favor ou contra o sufrágio universal, sua utilização seria incompreensível atacando ou defendendo um ponto de vista menos radical.

Os líderes do Exército utilizaram dois argumentos centrais contra os levellers. ${ }^{20} \mathrm{O}$ argumento inicial era que, fundamentando o direito de sufrágio a partir do direito natural, se estabelecia o direito natural como base generativa de direitos e de propriedade entre outras coisas, o que tinha duas consequências subversivas. Em primeiro lugar, a partir deste princípio era impossível justificar qualquer direito de propriedade:

[Ireton]: For us: by that same right of nature (whatever it be) that you pretend, by which you can say one man hath an equal right with another to the choosing of him that shall govern him - by the same right of nature, he hath the same [equal] right in any goods he sees meat, drink, clothes - to take and use them for his sustenance (Woodhouse, 1974, p. 58).

Em segundo lugar, em um governo constituído com base nestes princípios "os pobres poderiam excluir os ricos". Ireton utiliza um longo argumento para concluir esta ideia, porém a conclusão final fica claramente expressada:

[Ireton]: It may come to destroy property thus. You may have such men chosen, or at least the major party of them, [as to have no local and permanent interest]. Why may not those men vote against all property? (Woodhouse, 1974, p. 63).

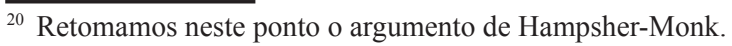


Ireton considerava que a extensão dos direitos políticos para os não proprietários levaria à expropriação dos proprietários. Como afirma Hampsher-Monk, a resposta colocada pelos líderes do Exército, e em particular por Ireton, é uma indicação forte de que a discussão se centrava no sufrágio universal e não em formas limitadas de sufrágio, criticando desta forma as teses de Macpherson ${ }^{21} \mathrm{de}$ que a proposta dos levellers não incluía o sufrágio universal. Independentemente das discussões sobre os limites das qualificações para votar, a proposta dos levellers implicava que o número de pessoas que teriam direito de votar deveria ser multiplicado várias vezes, daí a preocupação dos líderes do Exército com as consequências para as classes proprietárias (Hampsher-Monk, 1976, p. 401-2).

Ireton atacando a posição extrema dos levellers expunha as implicações concretas da proposta:

[Ireton]: You have five to one in the kingdom that have no permanent interest. Some men [have] ten, some twenty servants, so more some less. If master and servant shall be equall electors, then clearly those that have no interest in the kingdom will make it their interest to choose those that have no interest (Woodhouse, 1974, p. 63).

Os argumentos utilizados nesta parte dos debates reforçam a tese de que os levellers defendiam uma posição de princípio a favor do sufrágio amplo. Em primeiro lugar o argumento de Ireton estava dirigido contra alguém que está defendendo a inclusão dos criados [servants] no sufrágio. Em segundo lugar, não há nenhuma voz leveller que se defenda contra esta imputação. Por último, a relação entre o número de pessoas com direito a voto pelas regulações do momento e o número incluído na ideia de "sufrágio universal" é exatamente aquele colocado pelos coronéis Rainborough e Rich, e representa a diferença entre a posição dos líderes do Exército e os agitadores, isto é, uma relação de 5,5 a 1. Todos estes pontos foram colocados na discussão do argumento inicial contra a afirmação dos levellers do que este ponto pode ser chamado de proposta de sufrágio universal (Hampsher-Monk, 1976, p. 402).

Se os debates são lidos desta forma - como na análise de Hampsher-Monk - é possível conceber os levellers como defensores do sufrágio universal e, ao mesmo tempo, tornar inteligível o tipo de escolhas táticas realizadas pelos líderes do movimento. Se eles defenderam esta posição democrática em Putney, não existe justificativa para projetar nos panfletos anteriores uma interpretação

${ }^{21}$ O trabalho clássico de Macpherson (1979) tem colocado as posições políticas dos levellers como uma versão mais do "individualismo possessivo" presente em outros pensadores do século XVII como Hobbes e Locke. 
restritiva das aparentes reivindicações de direito universal. A explicação da expressão "livre por nascimento" [freeborn] pode ser interpretada de uma forma ampla, e não limitada, e sustentar que os levellers defendiam o direito de sufrágio universal desde o começo da sua atividade política em 1642 e até novembro de 1647, incluindo de modo óbvio os debates de Putney. Em The remonstrance of many thousands of the free people of England (1649), por exemplo, se oferece o voto a "todos os que venham até nós"; esta concepção também está presente em A charge of high treason against Oliver Cromwell em que, especificamente, se incluem no sufrágio "também os amos, filhos e criados".

Esta leitura pode, ao mesmo tempo, oferecer a possibilidade de analisar algumas mudanças importantes nas propostas colocadas pelos levellers, especialmente referidas ao Agreement, e avaliar até que ponto tratam-se de transformações fundamentais sobre o problema do sufrágio, ou mudanças de caráter conjuntural. O segundo Agreement (dezembro de 1648) explicitamente restringia o sufrágio, excluindo aqueles que recebiam caridade, os criados, ou aqueles que recebiam salários de qualquer indivíduo particular (Woodhouse, 1974, p. 357). O terceiro Agreement (maio de 1649) era mais amplo, pois estavam incluídos no sufrágio todos os homens maiores de vinte e um anos que não fossem criados, recebessem caridade, ou tivessem servido ao rei em armas ou com contribuições voluntárias (Wolfe, 1944b, p. 402-3). Os levellers, neste período, tentaram se movimentar politicamente de forma a conseguir maior consenso para suas propostas. No caso do segundo Agreement, é conhecida a tentativa de compromisso com os líderes do Exército e outros grupos; e a última versão parece expressar o documento mais independente apesar de certos compromissos assumidos (Thomas, 1972). A interpretação dessas mudanças é questão de disputa. Macpherson (1979) analisa as propostas como necessariamente excludentes de partes significativas da população, particularmente os assalariados e os mendigos, porém também pode ser argumentado que estas mudanças respondiam mais a opções de compromisso político; as evidências parecem permitir interpretações díspares.

Um dos pontos mais polêmicos refere-se à exclusão dos servants [que optamos por traduzir como criados], e à interpretação do sentido do termo. No século XVII, o termo servant podia ter vários significados. Macpherson deixa de lado possíveis ambiguidades e opta por uma interpretação ampla do significado equiparando servant com assalariado, qualquer um que trabalhe para outro por uma remuneração. No entanto, como afirma Thomas (1972), existe evidência que sugere que, no século XVII, o termo servant tinha um significado mais restrito, diferenciando este do assalariado. Os levellers, nos seus próprios manifestos, não equiparam servant com assalariado. No segundo Agreement, eles excluem 
os servants e "aqueles que recebem pagamentos de uma pessoa particular". Isto sugere que as duas categorias eram pensadas como diferentes. Assim, é possível concluir que em algumas das propostas apresentadas pelos levellers eles aceitavam a exclusão dos servants [criados], isto é, negavam os direitos políticos para aproximadamente $15 \%$ da população masculina adulta; e podemos acrescentar $0,1 \%$ se incluirmos os beggars [mendigos]. ${ }^{22}$ Ainda tomando em consideração as versões mais restritivas apresentadas pelos levellers, isto é, sem levar em conta as considerações que fizemos em relação aos debates de Putney, estamos frente a uma perspectiva de direitos políticos extraordinariamente mais inclusiva que qualquer outra proposta sobre o sufrágio anterior ao século XIX.

Uma conclusão provável das ambiguidades presentes nas posições dos levellers em relação ao tema do sufrágio está ligada a concessões de caráter tático e não a posições de princípio. Esta ideia de que as limitações do sufrágio se relacionavam com os compromissos políticos fortalece-se pelas conhecidas mudanças dos levellers em outros temas. A possibilidade de uma aliança com os presbiterianos, contra os líderes do Exército no inverno de 1647-8, levou os levellers a abrir mão das demandas pela abolição de títulos durante esse período. Outros panfletos do período oferecem uma predisposição favorável para com os partidários do rei, caso eles garantissem certas liberdades que os levellers consideravam mais provável obter sob o Stuart que com Cromwell. ${ }^{23}$ De qualquer forma, existem várias declarações inequívocas sobre direitos políticos universais anteriores e especialmente durante os debates de Putney; o período de exclusão dos criados e dos que recebiam auxílio foi um período de um ano e meio. Foi também o período de maior influência política, o que significa que o ponto alto de sua influência coincide com a proposta mais restritiva de sufrágio já feita. É razoável concluir que essa proposta de direitos limitados se deveu mais a uma estratégia consensual do ponto de vista político que a uma posição de princípios (Hampsher-Monk, 1976, p. 405-6).

\section{A questão da tolerância religiosa}

Uma última questão se refere à relação entre política e crença religiosa. Como vimos anteriormente, existia, no pensamento político leveller, uma série de elementos fundamentais para a construção de uma teoria radical da soberania popular. No entanto, existe outro elemento essencial para complementar

${ }^{22}$ Sobre os cálculos ver THOMAS, 1972, p. 73.

${ }^{23}$ Um exemplo disto é Legall fundamental liberties (1648), no qual Lilburne defende à necessidade do rei e do Parlamento como poder moderador frente ao exército, como forma de evitar a tirania deste. 
esta concepção democrática; este se relaciona com as crenças e com as práticas religiosas das seitas. ${ }^{24}$

Durante décadas as seitas tinham se separado da Igreja estabelecida, construindo novas igrejas a partir de contratos e acordos, e estas novas igrejas se estruturaram com base em princípios democráticos. Grande parte do apoio dos levellers, durante o período da guerra civil, provinha dos líderes de congregações separatistas. Lilburne era separatista, por volta de 1638, e Overton pertenceu a uma congregação batista, entre os anos de 1615-16. Os líderes levellers nunca reivindicaram uma influência direta dos princípios religiosos separatistas nas suas propostas políticas. Contudo, a relação entre política e religião é clara no pensamento político leveller. Richard Overton, por exemplo, afirmava que os primeiros cristãos se governavam por "consenso e eleição comum"; e as doutrinas políticas pregadas por teólogos importantes do período deixam em aberto a possibilidade de estender essas práticas da Igreja para o Estado. A prática democrática diária das seitas fez possível pensar algo que anteriormente era inconcebível, uma reforma institucional e um princípio de responsabilidade democrática.

No entanto, existia um componente contrário aos princípios democráticos no pensamento religioso das seitas; um elemento central da teologia clássica das seitas era a ênfase na diferença entre o pequeno grupo de eleitos, os santos congregados nas igrejas, e a grande massa de réprobos. Como era possível estender as práticas apropriadas para uma minoria piedosa à grande maioria de impiedosos? As igrejas congregadas dependiam de sua habilidade para expulsar os apóstatas da comunhão, entretanto, a República era uma comunidade necessariamente inclusiva e não exclusiva; era natural, consequentemente, para os puritanos afirmar que só os eleitos deviam governar. A pergunta, portanto, era como podia a teologia das seitas vincular-se com uma filosofia democrática? ${ }^{25}$

Uma das respostas a esta questão pode estar nas posições racionalistas adotadas por alguns pensadores levellers, que negavam o significado da queda, e desta forma a distinção puritana entre piedosos e impiedosos. Richard Overton, por exemplo, parece sustentar uma visão racionalista quando em Mans mortalitie (1646) argumenta que a alma é mortal e perece com o corpo para reviver só na ressurreição. Para Overton, a alma deve ser matéria, porque o que não é matéria não é nada e, assim como toda a matéria está composta por quatro elementos, "todos os homens sendo matéria criada, são elemento finito e mortal e, portanto,

\footnotetext{
${ }^{24}$ Sobre este ponto ver CHRISTOPHER HILL, 2001.

${ }^{25}$ Sobre esta tensão, ver também WOODHOUSE, 1974, p. 1-100 e HILL, 2001, p. 158-9.
} 
cessam do momento da sepultura até o tempo da ressurreição" (Overton, 1968, p. 11). A posição de Overton é uma posição racionalista, influenciada por pensadores como o físico Ambroise Paré, para quem o dogma da igreja perdeu sua influência (Zagorin, 1997).

William Walwyn, por sua vez, elaborou alguns dos melhores panfletos do período sobre a liberdade de consciência. Em The power of love (1643), faz um apelo para que as opiniões religiosas fossem examinadas com base na razão. $\mathrm{O}$ elemento dogmático é dissolvido e, com ele, a necessidade de uma pessoa com qualificações especiais para a interpretação da palavra de Deus. Não existe nada essencial para a iluminação religiosa do homem, afirma Walwyn, que Deus não tenha tornado acessível à capacidade do homem comum. Nenhum conhecimento especial é necessário, com a Bíblia em inglês qualquer homem pode declarar seu verdadeiro significado. Com a desaparição do dogma, a essência da verdadeira religião é alcançada como consequência.

No entanto, se argumentos de tipo racionalista influenciaram abertamente o pensamento político dos levellers, existiam também elementos que eram compatíveis com argumentos de tipo teológico.

Como afirma Woodhouse (1974, p. 65), um dos argumentos teológicos centrais para fundamentar uma filosofia democrática deve ser buscado na doutrina da liberdade cristã. ${ }^{26}$ Suas fontes estão no Novo Testamento, particularmente em São Paulo, mencionadas por Lutero na exposição das "Epístolas aos gálatas" e nas elaborações práticas da doutrina realizadas por Milton. Em termos simples, o Evangelho liberta os homens da autoridade da Lei. A essência da antiga lei divina é a escravidão, os homens são escravos de uma lei externa. A essência da nova lei é a liberdade: os crentes são filhos de Deus e seus herdeiros junto com Cristo; seu serviço é voluntário. A ideia é comum a todos os grupos protestantes e aceita, com ênfases diversas, por todos. Os limites desta liberdade estão colocados por duas questões centrais: que parte da Lei mosaica (cerimonial, judicial, moral) fica abolida no novo Evangelho? Quão ampla é esta liberdade, conferida como um dom puramente espiritual sem aplicações além da experiência religiosa do indivíduo? Sobre a primeira questão, Lutero e Milton colocam a mesma resposta extrema: não meramente a Lei cerimonial, mas a Lei mosaica como um todo deve

\footnotetext{
${ }^{26}$ As discussões sobre a doutrina da predestinação e o governo dos santos são extremamente complexas e, ao mesmo tempo, centrais dos debates internos do puritanismo e da revolução inglesa. Para os propósitos do presente texto faremos um recorte analítico para discutir aqueles elementos da doutrina puritana incorporados nos escritos dos pensadores levellers e, portanto, outros elementos não diretamente relacionados com a discussão serão negligenciados.
} 
ser suprimida. Sobre a segunda questão a resposta é nitidamente contrastante: Lutero limita sua aplicação à vida espiritual e à experiência do devoto, uma decisão característica de seu radicalismo religioso e conservadorismo prático. Milton, ao contrário, coloca a liberdade cristã como pedra angular de sua teoria sobre a tolerância; e, a partir da esfera religiosa, esta se estende ao domínio civil.

As consequências políticas dos argumentos teológicos foram de significativa importância para os diferentes grupos puritanos. Os presbiterianos não negavam a própria ideia de liberdade cristã, no entanto buscavam limitar as inferências derivadas dela e tentavam neutralizar seus efeitos apelando ao Antigo Testamento, a outras doutrinas teológicas e ao senso comum. Para aqueles - como os levellers - que enfatizavam a liberdade cristã e defendiam a liberdade de consciência como um direito de nascimento cristão, a doutrina era fonte genuína de emancipação. Esta doutrina se associava com, e de fato era um aspecto das, discussões sobre a relevância teológica do Antigo ou do Novo Testamento. Uma interpretação não conservadora interpretava o Novo Testamento como um elemento liberador. $\mathrm{O}$ Antigo Testamento era profético e simbólico, e seus modelos e preceitos, sob o Evangelho, não deviam ser interpretados de forma literal. A igreja-Estado de Israel não devia ser o modelo para uma nova igreja-Estado, mas meramente anunciar a verdadeira igreja; e, portanto, os mandamentos para purificar Israel da idolatria, heresia e blasfêmia, com a espada civil, não prescreviam obrigações para o magistrado cristão, eles expressavam a pureza de uma igreja de Cristo voluntária e verdadeira, e as censuras espirituais por cujos meios a pureza devia ser mantida. ${ }^{27}$

O princípio de liberdade cristã se articula com o princípio de igualdade que também tinha fundamentos teológicos. O sacerdócio do crente e a doutrina da eleição estabeleciam uma igualdade na esfera espiritual. A igualdade era independente das possessões e hierarquias e não tinha relação com elas. Da mesma forma que analisamos no princípio de liberdade cristã, a ideia de igualdade podia ser estendida: a igualdade dos crentes pode ser pensada como uma condição espiritual que contém certas implicações para a igreja. A questão não é só uma igreja livre, mas também uma igreja de iguais. A igualdade dos crentes serve como base para atacar, em primeiro lugar, a hierarquia da igreja e, em segundo, a distinção entre clérigos e laicos. É um princípio de caráter nivelador que pode ser estendido para fora da esfera eclesiástica de duas formas, e com resultados diametralmente opostos. Em uma primeira forma, o efeito não seria a igualdade absoluta, mas um novo tipo de privilégios; a igualdade dos crentes seria uma igualdade em uma

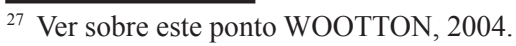


relação de superioridade em relação a outros homens. Esta é a visão discernível no pensamento dos presbiterianos e dos independentes; e alcança suas consequências lógicas no credo dos milenaristas, a doutrina acabada do privilégio dos santos. No entanto, onde o princípio de segregação é aplicado, o resultado é diferente, e a doutrina da igualdade dos crentes opera na esfera natural somente por analogia. Da mesma forma em que, na ordem da graça, todos os crentes eram iguais, também na ordem natural todos os homens eram iguais; da mesma forma que a Igreja era formada por crentes, todos com os mesmos privilégios, também o Estado devia estar formado por homens todos com os mesmos privilégios. A premissa foi a lição ensinada pelas seitas e sua conclusão foi colocada no âmbito político pelos levellers. Esta posição tinha fontes seculares nos conceitos de lei natural e de direitos naturais, porém estas ideias eram reforçadas, e era ao mesmo tempo conferida uma espécie de sanção religiosa pelo paralelo apresentado entre a ordem da natureza e a ordem da graça, e entre as ideias de liberdade e igualdade como apareciam no Estado e na igreja (Woodhouse, 1974, p. 68-71).

Os princípios teológicos anteriormente analisados, de liberdade e de igualdade, tinham consequências democráticas somente quando eram articulados com o princípio de segregação; este princípio significava uma divisão clara e, como consequência, a distinção entre a ordem da graça e a ordem da natureza, entre ordem espiritual e ordem secular. O principal âmbito de aplicação do princípio de segregação era a separação absoluta entre igreja e Estado. Este princípio também contribuía com a causa da liberdade, sendo suporte na argumentação a favor da tolerância religiosa. Ao mesmo tempo, destruía a ideia de uma igreja do Estado e de um Estado religioso; se espiritualizava a igreja, também secularizava o Estado e convidava a um novo exame de suas origens, funções e fundamentos. A secularização do Estado, portanto, oferecia possibilidades claramente democráticas (Woodhouse, 1974, p. 85).

Os levellers concebiam o Estado como uma instituição basicamente secular. Este devia ser instituído a partir dos princípios da razão natural e se devia deixar para o individuo questões de consciência privada que dependiam de crenças e não de um conhecimento seguro. As pessoas, de acordo com esta visão, não só não deviam ser obrigadas a ter crenças contrárias aos seus desejos, como também não podiam ser alienadas, em nenhum sentido, do direito de as seguirem.

Em Agreement of the people os levellers definem sua posição em assuntos de religião e de adoração da seguinte forma:

That matters of Religion, and the wayes of Gods Worship, are not at all intrusted by us to any humane power, because therein wee cannot remit or exceed a title of what our consciences dictate to be the mind of God without wilful sinne: neverthelesse the publike way 
of instructing the Nation (so it be not compulsive) is referred to their discretion (Wolfe, 1944, p. 227).

Esta concepção sobre o tema, em termos de direitos do indivíduo e não em termos de deveres do magistrado, separava os levellers dos independentes. Para os últimos, ainda se a razão natural não podia prover uma decisiva corte de apelação, a revelação claramente condenava a idolatria e requeria sua punição. No fim, a disputa entre os levellers e seus oponentes na questão da tolerância remetia à questão central da teologia, isto é, à relação entre o Antigo Testamento e o Novo Testamento. Para Ireton, o apelo ao Antigo Testamento era adequado; no entanto, para aqueles que defendiam a doutrina da graça este apelo não podia ser empregado para alterar ou estender, em nenhuma forma substancial, os ensinamentos do Novo Testamento.

Quando Walwyn insistia que a graça [doutrina da salvação] era unum necessarium [a coisa necessária], não era porque implicasse a salvação universal, mas porque esta doutrina requeria uma dicotomia entre o Antigo Testamento e o Novo Testamento, entre a Lei mosaica, que demandava obediência, e o Evangelho cristão, que oferecia salvação. Se o pecador podia ser salvo, era impossível, neste mundo, conhecer quem eram os santos que deviam governar e quem os réprobos que deviam obedecer. Desta forma, a doutrina da graça tinha claras implicações democráticas. Se a lei divina do Antigo Testamento devia ser abolida, o governo devia ser visto como obra do homem, de acordo aos princípios da razão natural e não organizado a partir de princípios divinos, e aquilo que o homem tinha feito também podia ser mudado por ele para servir mais adequadamente a seus propósitos. Se a graça era livre, como consequência, o magistrado não estava obrigado a punir a maldade para seu próprio bem-estar moral e como exemplo para os outros, e, somente, desde que fosse necessário, para a proteção da sociedade. O magistrado já não ocuparia um papel na salvação das almas dos homens, ou não estaria obrigado a prevenir que o ímpio dividisse o poder com o divino (Wooton, 2004, p. 441).

Richard Overton, em abril de 1649, sintetizava os temas centrais da questão da tolerância da seguinte forma:

As I am in myself in respect to my own personal sing and transgressions, so I am to myself and to God, and so I must give an account; the just must stand by his own faith. But as I am in relation to the Commonwealth, that all men have cognizance of, because it concerns their own particular lives, livelihoods and beings, as well as my own; and my failings and evils in that respect I yield up to cognizance of all men, to be righteously used against me. So that the business is, no how great a sinner I am, but how faithful and real to the Commonwealth; that's the matter concerneth my neighbour [...] And till persons 
professing religion be brought to this sound temper, they fall far short of Christianity; the spirit of love, brotherly charity, doing to all men as they would be done by, is not in them (Haller e Davis, 1964, p. 231).

Como afirma Wooton, os argumentos centrais da posição dos levellers fundavam-se em pressupostos teológicos: aqueles homens, criados livres em Adão, nasceram livres por natureza, tinham novamente sido feitos livres por graça de Cristo depois da servidão da Lei mosaica. Esta pressuposição não requeria a crença na livre vontade ou redenção geral; no entanto, implicava que o Antigo Testamento tivesse uma significação alegórica e não literal, e que a política fosse um assunto da razão natural e não da revelação. Estes pressupostos teológicos permitem explicar a inexistência de prebisterianos levellers e também a colaboração sempre cautelosa entre independentes e levellers. Como afirmava John Goodwin, durante os debates de Whitehall (Woodhouse, 1974, p. 125-178), colocar a visão religiosa leveller em uma constituição sugeria adotar uma posição teológica. Uma ação deste tipo não implicava uma tolerância prática para todas as visões religiosas e, sim, que o governo condenara a religião da maioria, o que se baseava em uma concepção diferente da graça (Wooton, 2004, p. 441-2).

Dessa forma, podemos concluir que os levellers eram cristãos que devido a razões teológicas aceitavam a tolerância religiosa e a ideia de uma sociedade secular como princípios políticos fundamentais; e ambos os elementos tinham claras consequências democráticas.

A partir dos argumentos apresentados anteriormente, é possível observar, nos argumentos defendidos pelos levellers, uma série de princípios políticos que se articulam de forma coerente, ainda que não de maneira sistemática. Em primeiro lugar, uma concepção de soberania popular. A partir das noções de lei natural, contrato, governo por consenso e dissolução do governo, os levellers vão defender a ideia de que a soberania última do poder político reside no povo e não no Parlamento; uma das evidências mais importantes da ideia de contrato e de soberania popular no pensamento político dos levellers é a proposta do Agreement of the people. Em segundo lugar, vão defender uma concepção radical de direitos naturais que os aproximou da noção de direitos inalienáveis da humanidade do século XVIII; o apelo à razão e aos direitos naturais, em oposição aos direitos históricos, permitiu que o movimento sustentasse a extensão dos direitos e não simplesmente a reivindicação dos já existentes. Em relação ao tema do sufrágio, como já analisamos, é possível afirmar que as ambiguidades presentes em relação ao tema dos direitos políticos se relacionam a concessões realizadas a partir de necessidades de caráter tácito. No entanto, como posição de princípio, os levellers 
eram a favor de um sufrágio amplo. Por último, os levellers, a partir de princípios teológicos, eram firmes defensores da tolerância religiosa e da noção de uma sociedade secular. Tanto a ideia do Estado como instituição basicamente secular, que devia ser instituído a partir dos princípios da razão natural, como a defesa do problema religioso como questão de consciência privada tinham implicações abertamente democráticas.

Ainda se estes princípios fossem considerados separadamente seria possível sustentar a ideia que os levellers foram um dos primeiros movimentos democrático-radicais da história. No entanto, foi a articulação destes princípios políticos, de uma forma coerente, que permitiu que eles fossem potencializados dando lugar à construção de uma das teorias democráticas mais radicais na Inglaterra do século XVII.

\section{Referências bibliográficas}

AYLMER, G. E. The levellers in the English revolution. Nova York: Ithaca, 1975.

BRAILSFORD, H. N. The levellers and the English revolution. Nottingham: Spokesman, 1983.

BURNS, J. H. The Cambridge history of political thought 1450-1700. Cambridge: Cambridge University Press, 2004.

DAVIS, J. C. The levellers and christianity. In: MANNING, B. S. Politics, religion, and the English Civil War. London: Arnold, 1973.

FOXLEY, Rachel. Problems of sovereignty in levellers writings. In: History of political thought, vol. XXVIII, n² 4, Winter 2007.

GENTLES, Ian. The Agreement of the people and their political context, 1647-1649. In: MENDLE, Michael (ed.). The Putney debates of 1647. The Army, the levellers and the English State. Cambridge: Cambridge University Press, 2001.

GOOCH, G. P. English democratic ideas in the seventeenth century. Nova YorkEvanston-London: Harper \& Row Publishers, 1959.

HALLER, W. e DAVIS, G. (eds.) The leveller tracts, 1647-1653. Gloucester: Peter Smith Pub Inc, 1964.

HAMPSHER-MONK, Ian. The political theory of the levellers: Putney, property and professor Macpherson. In: Political Studies, 24, n 4, dez. 1976, p. 397-422.

HILL, C. O mundo de ponta-cabeça. São Paulo: Companhia das Letras, 2001.

KISHLANSKY, Mark A. The rise of the new model Army. Cambridge: Cambridge University Press (1979) 2003.

LE CLAIRE, Lesley. The survival of the manuscript. In: MENDLE, Michael (ed.). The Putney debates of 1647. The Army, the levellers and the English State. Cambridge: Cambridge University Press, 2001. 
MACPHERSON, C. B. A teoria politica do individualismo possessivo. De Hobbes a Locke. São Paulo: Paz e Terra, 1979.

MEIKSINS WOOD, Ellen. Locke against democracy: Consent, representation and suffrage in the Two treatises. In: History of political thought, vol. XIII, $\mathrm{n}^{\circ} 4$, Winter 1992.

MEIKSINS WOOD, Ellen. Radicalism, capitalism and historical contexts: No only a reply to Richard Ashcraft on John Locke. In: History of political thought, vol. XV, n 3, Autumm 1994.

MENDLE, Michael (ed.). The Putney debates of 1647. The Army, the levellers and the English State. Cambridge: Cambridge University Press, 2001.

OVERTON, Richard. Mans mortalitie. H. Fisch (ed.). Liverpool: Liverpool University Press, 1968.

PLUMB, J. H. The growth of political stability in England, 1660-1730. London: Macmillan, 1967.

POCOCK, J. G. A. Linguagens do ideário político. São Paulo: Edusp, 2003.

POCOCK, J. G. A. Politics, language and time. Nova York: Atheneum, 1971.

POCOCK, J. G. A. The maquiavellian moment. Florentine political thought and the Atlantic republican tradition. Princeton: Princeton University Press, 2003.

SCOTT, J. Commonwealth principles: Republicans writing of the English revolution. Cambridge: Cambridge University Press, 2004.

SHARP, A. Introduction. In: SHARP A. (ed.). Political ideas of the English Civil Wars 1641-1649. Londres: Penguin Books, 1983.

SHARP, Andrew (ed.). The English levellers. Cambridge: Cambridge University Press, $2004 b$.

SHARP, Andrew. Introduction. In: SHARP, Andrew (ed.). The English levellers. Cambridge: Cambridge University Press, 2004a.

SKINNER, Q. As fundações do pensamento político moderno. São Paulo: Companhia das Letras, 2009.

THOMAS, K. The levellers and the franchise. In: AYLMER, G. E. (ed). The interregnum. The quest for settlement, 1646-1660. London e Basingstoke: The Macmillan Press Ltd., 1972.

TUCK, Richard. Natural rights theories. Their origin and development. Cambridge: Cambridge University Press, 1979.

WESTON, Corinne Comstock e GREENBERG, Janelle Renfrow. Subjects and sovereigns. Cambridge: Cambridge University Press, 1981.

WOLFE, D. M. Introduction. In: WOLFE, D. M. Leveller manifestoes of the puritan revolution. New York, 1944a.

WOLFE, D. M. Leveller manifestoes of the puritan revolution. Nova York, 1944b.

WOODHOUSE, A. S. P. Puritanism and liberty. Being and Army debates (1647-9) from the Clarke manuscripts. Chicago: J. M. Dent \& Son Ltd London, 1974. 
WOOLDRYCH, Austin. Soldiers and statesmen. The General Council of the Army and its debates 1647-1648. Oxford: Clarendon Press (1987) 2002.

WOOTTON, David (ed.). Divine right and democracy, an anthology of political writings in Stuart England. Cambridge: Hackett Publishing Company, 2003.

WOOTTON, David. Levellers democracy and the puritan revolution. In: BURNS, J. H. The Cambridge history of political thought 1450-1700. Cambridge: Cambridge, 2004.

WOOTTON, David. Levellers. In: DUNN, John. Democracy. The unfinished journey, 508 BC to AD 1993. Oxford: Oxford University Press, 1992.

ZAGORIN, Perez. A History of political thought in the English revolution. Dulles, Virginia: Thoemmes Press, 1997.

Recebido: 02/12/2009 - Aprovado: 24/02/2011 